\title{
SOLAR WALK ADS+: Explore Space as A Multimedia to Improve Students' Understanding and Believe in Learning Solar System
}

\author{
Renita Novitasari ${ }^{1}$, Hayat Sholihin ${ }^{2,}$ Eka Cahya Prima ${ }^{3}$ \\ \{renitanovita@gmail.com ${ }^{1}$, hsholihin@upi.edu, ekacahyaprima@upi.edu $\left.{ }^{2}\right\}$ \\ Department of Science Education, Faculty of Mathematics and Science Education, Universitas \\ Pendidikan Indonesia, Bandung, Indonesia ${ }^{1,3}$ \\ Department of Chemistry Education, Faculty of Mathematics and Science Education, Universitas \\ Pendidikan Indonesia, Bandung, Indonesia ${ }^{2}$
}

\begin{abstract}
The research is the first research that opens up our Universe from a mobile application called Solar Walk Ads+: Explore Space to improve students' understanding and believe in learning Solar System. The work has begun to collect the data of students' post-test and pre-test using quasi-experiment design participated by 12 students in 7th grade of a private school in Bandung, West Java. The data was analysed based on three different concepts, the higher improvement shows in the concept of the Solar System's effect on the phenomenon on the Earth. Meanwhile, the students' believe effect after learning with this application resulted in the better improvement shown for the lower achiever students rather than the higher achiever students. Finally, this research recommended to held research that finds out whether the improvement is better if learning Solar System using Solar Walk Ads +: Explore Space also motivates students to learn.
\end{abstract}

Keywords: Solar Walk Ads+, Interactive Media, Students' understanding, Students' believe, Solar System.

\section{Introduction}

The solar system is an essential subject to the science curriculum since it provides a new context in which the students can relate the understanding of physics principles in our universe. The students provided an opportunity to learn about what are the objects that exist in our solar system and how does it look like. In science itself, the solar system is a part of astronomy. Astronomy and astrophysics are subjects that tend to give a trigger in interest in pupils and students [1]. Since we cannot observe the objects directly, it is quite abstract to describe the solar system directly in the teaching-learning process. Thus, it makes there are so many opinions about the wrong concept of the Solar System.

Mobile learning also provides the students with the most realistic figure that can make the students believe what they learn, on- and off-line support need to be provided to build up mobile learning self-efficacy, and mobile learning mentor systems and user-friendly learning management systems could be good resources to increase self-efficacy [2].

Believe defined as self-efficacy, in which a person can successfully perform certain behaviors [3]. Therefore, the belief itself is one's ability to perform a task [4]. In the 
classroom, students with higher self-efficacy are more likely to persevere in difficult situations, see complexity as a challenge, and be engaged [4]. So, it is challenging for educators to adequately engage students and to make sure that participation in the classroom meaningful. Many universities proactively support teaching innovations and influence instructors to use educational technologies in class to increase the learning impact [5].

One of the teaching innovations nowadays is by using a mobile phone application as multimedia. Solar Walk Ads+ as a mobile phone application is one of the examples of multimedia in learning the solar system. In this research, Solar Walk Ads+ mobile phone application will stimulate the student's interest to increase their certainty. Because it is so interesting to use mobile devices in learning science [6]. Since in Solar Systems, many concepts need to be described clearly, the implementation of Solar Walk Ads+: Explore Space is to assist the students in understanding the situation of the solar system to make the abstract fact clearer and increase the students' believe in performing the task. First, the planets cannot be observed directly by human naked eyes. Second, the concept of earth rotation and earth revolution which quite abstract to be described without simulation. Therefore, the simulation itself helps the students in understanding learning solar systems. Based on this argumentation, a media learning tool can improve students' understanding and certainty in learning solar systems.

\section{Research Method}

The research method that will be used in this research is quasi-experiment. According to the experts, the quasi-experiment includes assignments, but not the random assignment of participants to groups. The researcher used this method because the researcher cannot mix the class randomly in the school. Researchers who employ quasi designs rely instead on other techniques to control (or at least reduce) threats to internal validity. The quasi-experimental approach introduces considerably more threats to internal validity than the true experiment. Because the investigator does not randomly assign participants to groups, the potential threats of maturation, selection, mortality, and the interaction of choice with other threats are possibilities.

This is because the experimenter cannot artificially create groups for the experiment. This method is appropriate with the purpose of the research, which is investigating The Effect of Solar Walk Ads as Interactive Multimedia on Student's Understanding and Motivation in Learning Solar System Topic.

\section{Result and Discussion}

The result of the research discussed in this chapter. The researcher analysed the result of the implementation of Solar Walk Ads+: Explore Space application as multimedia to improve students' understanding and believe in learning the solar system. The research conducted in Temasek Independent School, Bandung, West Java on 20 - 24 June 2019. The class that had chosen as the sample is 7 th grade of the Secondary Level. 


\subsection{Implementation of Solar Walk Ads+: Explore Space application}

Before implementing the Solar Walk Ads+: Explore Space application, the researcher has prepared several research instruments such as observation sheet, lesson plan, student's worksheet, student's group assessment, students' feedback, and the application. The instruments help the researcher implementing the researcher in conducting this research.

Solar Walk Ads+: Explore the Space app. It has several features that can be used as multimedia to learn Solar System. To know whether Solar Walk Ads+: Explore Space can be used in this research; the compatibility check has been made. Table 1 shows the compatibility of the Solar Walk Ads+: Explore Space application to the concept of Solar System based on the 2013 curriculum.

Table 1. Compatibility of Solar Walk Ads+: Explore Space app. with the Concept and Indicator.

\begin{tabular}{|c|c|c|c|}
\hline No & Concept & The indicator in 2013 Curriculum & Application content \\
\hline \multirow[t]{2}{*}{1.} & $\begin{array}{l}\text { Characteristics of the } \\
\text { Solar System's } \\
\text { components }\end{array}$ & $\begin{array}{l}\text { Describing the characteristics of the } \\
\text { Solar System's component }\end{array}$ & $\begin{array}{l}\text { 3D animation of Solar System } \\
\text { components as of the planets, } \\
\text { asteroids, satellites }\end{array}$ \\
\hline & & $\begin{array}{l}\text { Searching for information about the } \\
\text { planets of the solar system. }\end{array}$ & $\begin{array}{l}\text { Information of the planets in the } \\
\text { solar system including the general } \\
\text { information, history, figures, } \\
\text { internal structure, and atlas }\end{array}$ \\
\hline \multirow[t]{3}{*}{2.} & $\begin{array}{l}\text { The planetary } \\
\text { motion }\end{array}$ & $\begin{array}{l}\text { Describing the planetary motion on } \\
\text { its orbit of the solar system. }\end{array}$ & $\begin{array}{l}\text { Simulation of the planetary motion } \\
\text { towards the Sun based on the time }\end{array}$ \\
\hline & & Observing various Moon phase. & $\begin{array}{l}\text { Video of the Moon phase and its } \\
\text { explanation }\end{array}$ \\
\hline & & $\begin{array}{l}\text { Describing the movement of Earth's } \\
\text { rotation and revolution }\end{array}$ & Video of Earth cycle, \\
\hline \multirow[t]{2}{*}{3.} & $\begin{array}{l}\text { Effect of Solar } \\
\text { System to the } \\
\text { phenomenon on the }\end{array}$ & $\begin{array}{l}\text { Describing the movement of Earth's } \\
\text { rotation and revolution as well as } \\
\text { the event that affected by it. }\end{array}$ & $\begin{array}{l}\text { Video of Earth cycle, tidal } \\
\text { phenomena, and Solar eclipse }\end{array}$ \\
\hline & & $\begin{array}{l}\text { Searching for information about } \\
\text { change season that happened in the } \\
\text { northern part of the Earth and Earth } \\
\text { southern part }\end{array}$ & Video of Earth cycle \\
\hline
\end{tabular}

Solar Walk Ads+: Explore Space is compatible with the indicators that needed in learning Solar systems based on the 2013 curriculum. The application will be used by the students on their mobile phones. Besides, the researcher also presented the application on the LCD screen. Solar Walk Ads+: Explore Space application has been implemented in the class with the help of one observer. The observer checked the observation sheet that has been prepared by the researcher to check the teacher and the students' activities in the class which must be in line with the lesson plan.

The display of Solar Walk Ads+: Explore Space shows the Planets in Solar System that can be pinched in and out as we can see in Figure 1. In this application, the students were able 
to get information about the components of the Solar System, watch several phenomena on the earth caused by the Solar System, and see some satellites launched.

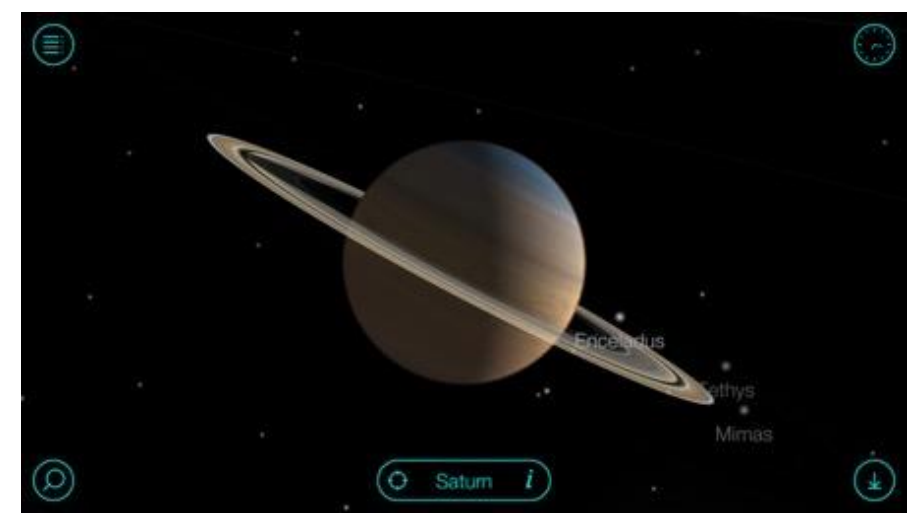

Fig. 1. Display of Solar Walk Ads+: Explore Space.

In the first meeting, to help the students in using the application, two worksheets have been made. The worksheets made with the help of the Canva website to enhance the design to make the students interested. The first worksheet used to introduce the Solar Walk Ads+: Explore Space application. Moreover, the student made the model of the solar system as seen in Figure 2.

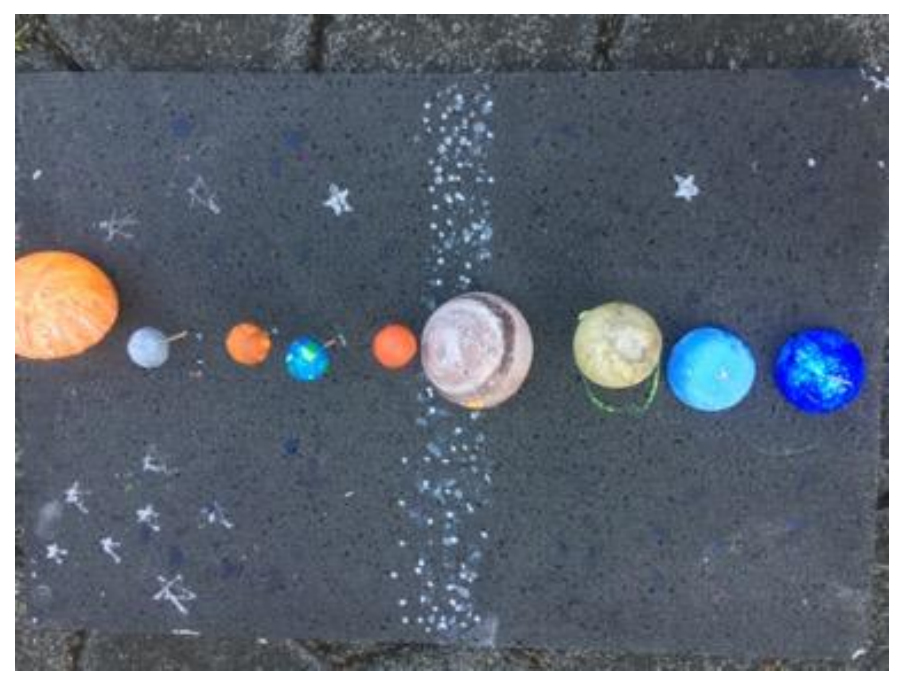

Fig. 2. The Solar System Model by the a group of Students.

Based on the lesson plan on the first meeting, the Solar Walk Ads+: Explore Space applied very well. As the application shows the planet clearly, the students can make the model of the Solar System as close as it seems in real condition. Using the information from the Solar Walk Ads+: Explore Space, the first topic taught by making a project of Solar 
System's model using used Styrofoam and acrylic color. This result means that the students able to make an abstract concept become concrete. Figure 2 shows one of the results of the students' Solar System Model. Based on the observational sheet, all of the activities that related learning Solar System using Solar Walk Ads+: Explore Space has been implemented. From the data that has been collected from the observer, the percentage of the activities that have been implemented is $100 \%$. The result can be interpreted that the Solar Walk Ad+: Explore Space can be implemented in Learning Solar System as a media with the help of worksheets and learning activities such as making projects.

\subsection{The improvement of Students' Understanding}

The improvement of students' understanding of learning Solar systems is divided into three main concepts which are the characteristics of the Solar System components, the planetary motion, and the effect of Solar System to the phenomenon on the Earth. Those concepts were distributed in 30 numbers of multiple-choice questions used in the pre-test and post-test

The Solar System topic in this research has been divided into three main concepts. The first concept is the characteristics of the Solar System's components. The second concept is the planetary motion. And the third concept is the effect of the Solar System to the phenomenon on the Earth. The improvement of the students' understanding can be seen in the data's recapitulation shown in Table 2 .

Table 2. Average Score of Pre-test and Post-Test based on main concept and level cognitive.

\begin{tabular}{lllllll}
\hline No. & Main Concept & Question number & $\begin{array}{l}\text { Pre- } \\
\text { test }\end{array}$ & $\begin{array}{l}\text { Post- } \\
\text { test }\end{array}$ & N-gain & Category \\
\hline 1. & $\begin{array}{l}\text { Characteristics of } \\
\text { the Solar System's } \\
\text { components }\end{array}$ & Total of 15 questions & 17.78 & 35.56 & 0.52 & Fair \\
2. & $\begin{array}{l}\text { The planetary } \\
\text { motion. Total of 6 questions }\end{array}$ & 7.78 & 15.56 & 0.64 & Fair \\
3. & $\begin{array}{l}\text { The effect of Solar Total of 9 questions } \\
\text { System to the } \\
\text { phenomenon on } \\
\text { the Earth } \\
\text { Summary }\end{array}$ & 10.00 & 23.89 & 0.69 & Fair \\
\hline
\end{tabular}

It can be found that the average score of the pretest score is increasing. Thus, there is a significant increment of the students' understanding of learning Solar systems based on the result of higher post-test scores than the pre-test score.

Besides, by comparing pre-test and post-test scores, the researcher got a normalization value of 0.6 which categorized as fair in improvement based on Hake's rule of normalization. The pre-test and the post-tests result is not only analyzed by the Normalized gain. The hypothesis test also being tested using SPSS for Windows, 24 version. The data analyzed by descriptive statistics so that we can get further information about it. The result of the descriptive statistics is shown in Table 3

Table 3. Descriptive Statistics. 


\begin{tabular}{lllllc}
\hline & $\mathrm{N}$ & Minimum & Maximum & Mean & Std. Deviation \\
\hline Pre-test & 12 & 23 & 53 & 35.4 & 8.2 \\
$\begin{array}{l}\text { Post-test } \\
\text { Valid }\end{array}$ & 12 & 43 & 87 & 75.0 & 3.2 \\
\begin{tabular}{l} 
(listwise) \\
\hline
\end{tabular} & 12 & & & & \\
\hline
\end{tabular}

There is a huge significant increment in both minimum and maximum scores from the pretest to the post-test. The normality test then conducted with the aims is to find out whether the data is normally distributed or not. Furthermore, the data analyzed by a parametric or nonparametric test based on the result of the normality test. Since all of the significance value's result is above 0.05 for the data that has been tested, it means that the data is normally distributed.

Based on the data from the parametric test which is a paired sample test, the data has a $95 \%$ confidence interval of the difference which means there is a 5\% (0.05) interval of the difference. The Sig. ( 2 tailed) value is 0.000 which less than 0.05 . It means that there is a difference in the average score of the pretest and the post-test.

\subsection{The improvement of Students' Believe}

The result of the students' believes assessed using the questionnaire of Self-Efficacy by Bandura in 2006. Ten tasks being questioned in this questionnaire. In the classroom, students with higher believe are more likely to persevere in stressful situations, see complexity as a challenge, and be engaged [7]. This means, the effect of Solar Walk Ads+: Explore Space application in the improvement of the students' ability to accomplish specific tasks in learning Solar System will make the students able to perform well in the lesson. Table 4 presents the result of a Student's believes in performing the task in the class during the implementation of Solar Walk Ads_: Explore Space application.

Based on Table 4, all of the students are almost highly certain can use their mobile phone to learn Solar System. This is means that students nowadays can use their phones for learning purposes. With the average score of 90 , this means almost all students were able to use their mobile phones to learn Solar System. Five students are highly certain that they can use Solar Walk Ads+: Explore Space application to learn Solar System. While the rest of them are moderate can use it in the score 50 above. 
Table 4. Students' Believe Questionnaire recapitulation result.

\begin{tabular}{|c|c|c|}
\hline No. & Questionnaire's Question & Average Score \\
\hline 1. & Evaluate My Own Work & 68.8 \\
\hline 2. & Evaluate My Friend's Performance & 79.2 \\
\hline 3. & Present My Group's Project in front of the Class & 73.3 \\
\hline 4. & $\begin{array}{l}\text { Create a Solar System Model Using Solar Walk Ad+ } \\
\text { Application as The Source }\end{array}$ & 72.5 \\
\hline 5. & Draw Solar Eclipse diagram & 82.1 \\
\hline 6. & $\begin{array}{l}\text { Draw Moon Phase Based on } \\
\text { The Moon and The Sun Position }\end{array}$ & 85.0 \\
\hline 7. & $\begin{array}{l}\text { Demonstrate the movement of earth and moon rotation and } \\
\text { revolution towards the sun }\end{array}$ & 86.5 \\
\hline 8. & $\begin{array}{l}\text { Share the information to my friend about the event that } \\
\text { affected by earth's rotation and revolution }\end{array}$ & 78.3 \\
\hline 9. & Use the mobile phone to learn Solar System & 90.0 \\
\hline 10. & Use Solar Walk Ad+ application to learn Solar System & 91,7 \\
\hline
\end{tabular}

The result of students' average in this indicator is the highest among other indicators that are 91.7. The result was very high, this means that Solar Walk Ads+: Explore Space application can be used as multimedia for the students to learn Solar System. Regarding all of the aspects above, we can conclude that the implementation of Solar Walk Ads+: Explore Space as multimedia helps the students to believe that they can do the activity in learning the Solar System.

Regarding all of the aspects above, we can conclude that the implementation of Solar Walk Ads+: Explore Space as multimedia helps the students to believe that they can do the activity in learning the Solar System.

\section{Conclusion}

While the study about this application is still rare, the researcher concluded based on the research that has been conducted that Solar Walk Ads+: Explore Space provides the Solar System materials in the curriculum 2013 are covered by the application with the help of worksheets. Solar Walk Ads+: Explore Space application can be used as multimedia to help the students improve their understanding of learning Solar System. As well as the students' understanding, the implementation of students' believes also have a positive impact on the students. The lower achiever students do even think that they can perform the tasks in learning Solar systems higher than the high achiever. SOLAR WALK ADS+ : Explore Space can be used as a multimedia to help the students improving their understanding and believe, several recommendations that needed to improve the implementation of the research in the future are by set the timing for the validation of the instrument longer than a week apply the application in the Senior High School students. 


\section{References}

[1] Persson, J. R. and Eriksson, U. Planetarium software in the classroom. Physics Education, 51(2), pp. 025004 (2016)

[2] Park, S.Y., Nam, M.W. and Cha, S.B.: University students' behavioral intention to use mobile learning: Evaluating the technology acceptance model. British Journal of Educational Technology, 43(4), 592-605 (2012)

[3] Bandura, A. Self-efficacy: toward a unifying theory of behavioural change. Psychological review, 84(2), pp. 191 (1977)

[4] Pajares, F.: Schooling in America: Myths, mixed messages, and good intentions. Lecture delivered at Emory University, Cannon Chapel. Great Teachers Lecture Series (2000)

[5] Saeed, N., Yun, N. and Sinnappan, S.: Emerging web technologies in higher education: A case of incorporating blogs, podcasts and social bookmarks in a web programming course based on students' learning styles and technology preferences. Journal of Educational Technology \& Society, 12(4), pp. 98-109 (2009)

[6] Crompton, H.: A historical overview of mobile learning: toward learner-centered education. In: Berge ZL, Muilenburg LY (eds) Handbook of mobile learning. Routledge, Florence, pp. 3-14 (2013) [7] Krathwohl, D. R., and Anderson, L. W.: Taxonomy for learning, teaching, and assessing: A revision of Bloom's taxonomy of educational objectives. Theory into practice, 41(4), pp. 212 (2001) 